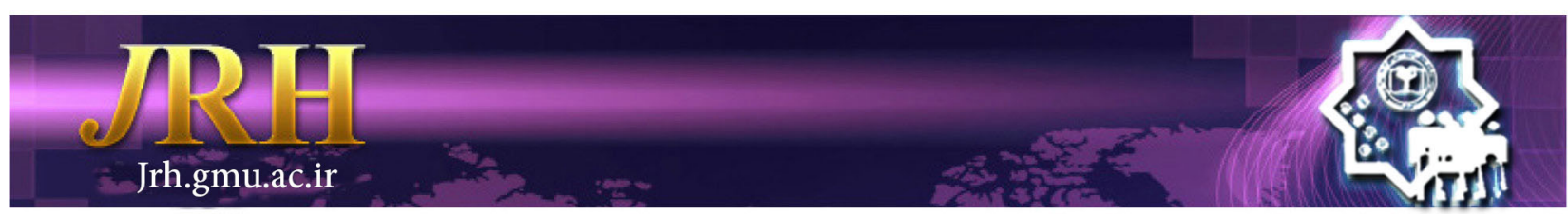

\title{
Relationtionship between neurological and psychological symptoms and occupational exposures
}

Seyedeh Negar Assadi ${ }^{1,2}$

\author{
Journal of Research \& Health \\ Social Development \& Health Promotion \\ Research Center \\ Vol. 8, No. 1, Jan \& Feb 2018 \\ Pages: 79- 84 \\ DOI: 10.29252/acadpub.jrh.8.1.79 \\ Original Article
}

\section{Correspondence to:}

1. Social Determinants of Health Research Center, Mashhad University of Medical Sciences, Mashhad, Iran

2. Department of Environmental and Occupational Health Engineering, School of Health, Mashhad University of Medical Sciences, Mashhad, Iran

Email: assadin@mums.ac.ir

Received: 15 Sep 2015

Accepted: 3 Sep 2016

How to cite this article: Assadi SN. Relationtionship between neurological and psychological symptoms and occupational exposures. $J$ Research \& Health2018; 8(1): 79- 84.

\begin{abstract}
Environmental exposures of workplace may affect employees' health including the nervous and psychological systems. Aim of this study was to determine the effects of occupational factors on psychological and neurological systems in workplaces. This is historical cohort study on employees in low and high exposure groups. The study's tool was flexible interview, questionnaire and occupational factors measurement. Sick employees were followed until the end of treatment. Headache was higher in employees with high level of lighting. The relative risk was 1.45 (1.04-2.02). Dizziness was significantly more in the working hours in offices. The risk ratio for dizziness was 2.25 (1.80-2.33). Employees with high exposure to occupational factors were at higher risk for headache and dizziness. There is relationship between loss of concentration and age. The risk ratio was 1.63 (1.13-2.36). The results of this study indicated that people who exposed to occupational and environmental pollutants occupational might be a risk for some psychological and neurological symptoms such as headache and dizziness and impaired concentration would be increased by aging.
\end{abstract}

Keywords: Neurological Symptoms, Occupational Factors, Psychological Symptoms

\section{Introduction}

The environmental factors can affect the human health especially in the workplaces. There are noise, light, carbon monoxide, carbon dioxide, mean temperature. [1] Some factors such as duration of work, age, gender, and previous disorders may be risk factors. [1,2]

Some studies showed the effect of occupational factors on the workers' health such as hearing and risk of hearing loss [1], occupational heart and lung diseases [2] but a few studies worked on the administrations because of low exposures and less concentrations. Some of occupational factors could be harmful in lower concentration so complementary studies were required.

Headache, fatigue, dizziness, nausea, loss of concentration, loss of memory, stress [3-6], feel to be under control, job dissatisfaction [7] are the most important symptoms that could be affected the ability of doing jobs and tasks in the workplaces . Each of them could be found in some disorders and has specials causes. [8,9] But occupational and environmental factors is one of the important items in the etiology because it is changeable [10].

According to the scientific literature, lower level of noise can influence psychological and nervous systems [11-13]. The symptoms were headache, fatigue, nausea, dizziness, loss of concentration, stress. Because of the prevention in the workplace, level of noise 
must be measured and assessed. Some studies investigated etiological effect of noise on these symptoms. In other researches effects of metals and chemicals on hearing [14-16] and nervous system $[17,18]$ were studied. A few studies were worked on effects of light in the workplace, this factor could influence on neurological system $[19,20]$. The light could be trigger headaches, nausea and also fatigue. According to the scientific literature, carbon monoxide had negative effect on nervous and psychological system and this factor can cause headache, fatigue, dizziness, nausea, loss of concentration and loss of memory. Researchers found that there is relationship between indoor air pollution and related illness [21-23] and another studies showed the causal effects of indoor air pollution in sick building syndrome [24-26] . Carbon monoxide is more important in cold season with incomplete combustion of fuels. Though carbon monoxide concentrations were lower than standards but some of studies demonstrated its effects.

Temperature was an important factor because could change the comfortable workplace to uncomfortable place which may be caused mental and physical disorders [19,20].

Some of the occupational and environmental exposures effects were unknown and researcher wanted to find them.

Aim of this study was to determine the effects of occupational factors on psychological and neurological systems in workplaces.

\section{Method}

This is historical cohort study on employees in low and high exposure groups which was conducted on employees about psychological and neurological symptoms in Khorasan Razavi province, Iran. Study population was administrative employees of 82 administrations. Sick employees were followed until the end of treatment. Study population was calculated 1000 for each group (low and high levels of risk factors) by simple random sampling method according to references [1-3] with $\alpha=0.05$, power $=0.80, \mathrm{P}_{1}=22 \%$ and $\mathrm{P}_{2}=12 \%$. Inclusion criteria were personnel of administrations with at least 1 years work experience. Exclusion criteria were any previous history of psychological and neurological disorders before entering their present occupation.

Participants were evaluated and observed for age, gender, and other related diseases.

The study's tool was flexible interview, questionnaire and occupational factors measurement. The questionnaire validity and reliability were investigated by professors' opinions and also through a pilot study by employees with a correlation coefficient $85 \%$. It was standard questionnaire from National Institute of Occupational Safety and Health (NIOSH) with related items. [6]

This questionnaire has items regarding headache, fatigue, nausea, dizziness, memory loss, loss of concentration, stress, under control, job dissatisfaction. Questionnaires also include questions about non occupational and occupational risk factors for related disorders. Non occupational risks were age, gender, body mass index, psychological stress, and occupational risks were work stress; physical or mental, exposures to chemical and physical factors, shift work In this part author measured the noise (noise dosimeter), lighting (lux meter), carbon monoxide ( real time- pump sampling), carbon dioxide( real time- pump sampling) and temperature (thermometer) of the administrations as risk factors measurement.

Data were analyzed by frequency Tables, mean, and t-test were used to compare quantitative variables such as; noise, lighting, carbon monoxide, carbon dioxide and temperature and $\chi 2$ for qualitative variables $(\mathrm{p}<0.05)$.

Study protocol had been done by taking the participants' oral consent according to ethical consideration. Author told about the participatory situations and regulations.

\section{Results}

In this study, 2000 participants from administrations with high or low level of environmental risk factors were participated. Researcher found the two levels of risk factors low and high level. These were determined as age was less than 35 years (low) 35 years and 
more (high), work experience was less than 15 years (low) 15 years and more (high), work with computer in a day was less than 4 hours (low) 4 hours and more (high), noise was less than $65 \mathrm{~dB}$ (low) $65 \mathrm{~dB}$ and more (high), lighting was less than 600 Lux (low) 600 Lux and more (high), temperature was less than $22.5^{\circ} \mathrm{C}$ (low) 22.5 and more (high), Carbon monoxide was less than 5 ppm (low) 5 ppm and more (high), Carbon dioxide was less than 500 ppm (low) 500 ppm and more (high).

The environmental risk factors were measured and calculated as the mean of work duration in high level was $24.87 \pm 2.64$ years and in low level was $4.83 \pm 4.03$, noise in high level was $74.25 \pm 3.53 \mathrm{~dB}$ and in low level was $55.91 \pm 3.44$ $\mathrm{dB}$, lighting in high level was 756.66 \pm 213.61 and in low level was 361.56 \pm 129.48 lux, carbon monoxide concentration in high level was $5.92 \pm 1.25$ PPM and in low level was $3.16 \pm 0.40$ PPM, carbon dioxide concentration in high level was 622.22 \pm 66.66 PPM and in low level was $450.0 \pm 70.71$ PPM, mean of temperature in high level was $22.87 \pm 0.99^{\circ} \mathrm{C}$ and in low level was $17.75 \pm 1.38^{\circ} \mathrm{C}$ all of them were significant $(p<0.05)$.

\begin{tabular}{|c|c|c|c|c|c|}
\hline Factors & $\begin{array}{l}\text { High noise } \\
\text { RR(CI) }\end{array}$ & $\begin{array}{l}\text { High lighting } \\
\text { RR(CI) }\end{array}$ & $\begin{array}{l}\text { High Carbon } \\
\text { monoxide } \\
\text { RR(CI) }\end{array}$ & $\begin{array}{l}\text { High Carbon dioxide } \\
\text { RR(CI) }\end{array}$ & $\begin{array}{l}\text { High temperature } \\
\text { RR(CI) }\end{array}$ \\
\hline Headache & $1.00(0.127-7.893)$ & $1.45(1.04-2.02)$ & $1.02(0.05-1.01)$ & $1.33(0.96-0.84)$ & $2.00(0.250-15.99)$ \\
\hline Fatigue & $1.45(1.04-2.02)$ & $2.57(0.192-34.47)$ & $1.03(0.04-4.03)$ & $3.50(0.208-58.77)$ & $1.87(0.30-11.62)$ \\
\hline Nausea & $2.22(0.192-25.72)$ & $0.857(0.124-5.94)$ & $1.25(0.09-1.07)$ & $0.769(0.57-1.03)$ & $1.22(0.07-1.01)$ \\
\hline Dizziness & $0.667(0.084-5.30)$ & $4.66(0.67-32.36)$ & $1.08(0.8-16.23)$ & $0.667(0.420-1.05)$ & $2.57(0.19-34.47)$ \\
\hline
\end{tabular}

Table 1 shows the relative risk of neurological symptoms in high level of exposures. $(p<0.05$.) Headaches were higher in administrative employees with high level of lighting $(\mathrm{p}<0.001)$. The relative risk was 1.45 (1.04-2.02). Fatigue was more in persons with more duration of work but this one was not significant difference $(p=1.0)$. Headaches were higher but not significant in administrative employees with high level of carbon monoxide $(p=1.0)$. Fatigue was more in persons with more carbon dioxide concentration but this was not significant difference $(p=0.179)$.

Table 2 The ratio risk of psychological symptoms in high level exposure

\begin{tabular}{lccccc}
\hline Sactors & $\begin{array}{c}\text { High Noise } \\
\text { RR(CI) }\end{array}$ & $\begin{array}{c}\text { High Lighting } \\
\text { RR(CI) }\end{array}$ & $\begin{array}{c}\text { High } \\
\text { Carbon monoxide } \\
\text { RR(CI) }\end{array}$ & $\begin{array}{c}\text { High Carbon } \\
\text { dioxide } \\
\text { RR(CI })\end{array}$ & $\begin{array}{c}\text { High Temperature } \\
\text { RR(CI) }\end{array}$ \\
\hline $\begin{array}{l}\text { Loss of memory } \\
\text { Loss of }\end{array}$ & $3.66(0.273-49.28)$ & $1.09(0.920-1.29)$ & $6.00(0.81-44.35)$ & $9.80(0.89-106.84)$ & $1.09(0.920-1.29)$ \\
concentration & $1.23(0.97-1.55)$ & $0.667(0.30-1.48)$ & $0.50(0.03-6.68)$ & $0.30(0.02-4.06)$ & $1.06(0.94-1.21)$ \\
Stress & $0.167(0.012-2.36)$ & $0.923(0.78-1.08)$ & $0.857(0.124-5.94)$ & $0.583(0.078-4.38)$ & $1.20(0.839-1.716)$ \\
Under control & $1.50(1.43-6.68)$ & $0.889(0.706-1.12)$ & $0.333(0.05-2.17)$ & $0.340(0.05-2.26)$ & $1.11(0.90-1.36)$ \\
Job dissatisfaction & $0.50(0.03-6.68)$ & $1.11(0.90-1.36)$ & $0.125(0.01-0.99)$ & $0.33(0.051-2.17)$ & $0.88(0.70-1.12)$ \\
\hline
\end{tabular}

Table 3 The ratio risk of neurological, psychological symptoms in high age level, gender of men and work hours symptom.

\begin{tabular}{lccc}
\hline Symptoms & Variables & High age level & Gender of men \\
RR(CI $)$ & $(\mathrm{CI})$ & $\begin{array}{c}\text { Work time symptoms } \\
\text { RR(CI) }\end{array}$ \\
\hline Headache & $0.267(0.032-2.24)$ & $0.615(0.04-8.70)$ & $1.33(0.165-10.74)$ \\
Fatigue & $2.50(0.34-18.33)$ & $0.35(0.02-4.65)$ & $5.62(0.747-42.35)$ \\
Nausea & $1.12(0.5-6.23)$ & $1.25(0.2-1.23)$ & $1.11(0.10-14.20)$ \\
Dizziness & $1.20(0.08-16.23)$ & $1.21(0.97-1.51)$ & $2.25(1.80-2.33)$ \\
Loss of memory & $1.20(0.08-16.23)$ & $1.21(0.97-1.51)$ & $4.80(0.350-65.75)$ \\
Loss of & $1.63(1.13-2.36)$ & $1.18(0.97-1.44)$ & $3.16(0.63-6.13)$ \\
concentration & $0.75(0.11-4.89)$ & $1.42(0.952-2.14)$ & $1.55(0.244-9.91)$ \\
Stress & $1.50(0.22-10.21)$ & $1.60(0.935-2.73)$ & $2.14(0.299-15.35)$ \\
Under control & $1.62(0.12-2.35)$ & $9.50(0.56-35.24)$ & $1.58(0.12-2.23)$ \\
Job dissatisfaction & & & \\
\hline
\end{tabular}


Table 2 demonstrates the relative risks of psychological symptoms in high level of exposures. $(p<0.05$. $)$ Regarding the relation between work experience and stress; the persons with more work duration had more stress but it was not significant $(p=0.22)$.

Table 3 shows the relative risks of symptoms in higher age level, gender of men and work time symptoms. Loss of concentration was high in more level of age $(p=0.02)$. Dizziness was significantly more in working hours in workplaces $(p=0.001)$. The relative risk for dizziness was 2.25 (1.80-2.33).

\section{Discussion}

According to the results the occupational and environmental risk factors were measured and calculated; all of them were significant between two groups of low and high level of exposures. Headache was higher in employees with high level of light. The relative risk was 1.45 and confidence intervals were 1.04 to 2.02. Effects of light on triggering the some kind of headaches have been shown in other studies [25]. Fatigue was higher in persons with more duration of work but this one was not significant difference. Some studies were found that chronic fatigue syndrome and burn out had more incidences in older working ages [25]. Many of these employees were in beginning years of working There was high headache but not significant in employees with high level of carbon monoxide $(p=1.0)$. According to the scientific literatures carbon monoxide could be affected by nervous system [24]. In this study concentrations were not higher than the standards.

Fatigue was more in persons with more carbon dioxide concentration but this one was not significant difference. Other studies were showed the same results for neurological symptoms [14-18]. In standard levels there was not fatigue symptom. In this study the concentrations were moderate in some situations but ventilation systems and windows could be delivered pollution to outdoor.

Regarding the relation between work experience and stress; the persons with more work duration had more stress but not significant. According to the scientific literature one kind of work stress was career development, this kind of stress was more in older working ages and defined for new responsibility, stress of job loss and have not opportunity for job development [3].

Loss of concentration was more in high level of age. The relative risk was 1.63 with confidence interval were 1.13 to 2.36 . Job dissatisfaction was more in high level of age but was not significant. Other studies were showed the same results for psychological symptoms $[6,10]$. Age could be caused many neurological and psychological symptoms and signs such as loss of concentration and memory, those were need to appointment a neurologist or psychiatric for prevention of important and main diseases in this situations. According to the results, person who exposure to noise had more stress and they thought that others controlled them [1]. In this study there was not this problem because noise was controlled.

Dizziness was significantly more in the administrations during work. The relative risk for dizziness was 2.25 with confidence interval were 1.80 to 1.33 . Dizziness was significantly better in the weekends and off days, the work place could be affect on this symptoms. Long time working with computer could be caused dizziness.[25]

In this study, researcher performed exact analysis and some data were gathered from employees' memory. It seems that other etiology or complexity of reasons might be caused these symptoms so must be studied in researches. Occupational assessment and measuring of risk factors could be prevented high exposures and related disorders.

Periodical physical examination of employees could be helpful for prevention of the related disorders [27-30]. In some situation filling the questionnaire may be useful specially for psychological symptoms [31,32]. But interviewing should be done for better understanding of probably health problem. Unfortunately, the number of personnel who were able to participate in the study after 
considering exclusion criteria was low. It seems that complementary study can be helpful. Assessment of other risk factors in relation to neurological and psychological symptoms and signs would be necessary.

Based on our study, we propose that job analysis and determination of occupational risk factors for employees is necessary.

\section{Conclusion}

Occupational and environmental pollutants occupational might be a risk for some psychological and neurological symptoms such as headache and dizziness and impaired concentration would be increased by aging. Dizziness might be caused by working with computers for along times. If they rest some times between working hours they will not have dizziness at all. Working with lower lights could be treated their headaches in working hours and also some times after that. Light should be used in proper intensity. Author recommended recording of history and physical examinations for employees.

\section{Acknowledgements}

The author appreciated the supports of Mashhad University of Medical Sciences.

\section{Contribution}

Study design: SNA

Data collection and analysis: SNA

Manuscript preparation: SNA

\section{Conflict of Interest}

The author declares that she has no competing interests.

\section{Funding}

The authors are grateful to Mashhad University of Medical Sciences for financial support (No. 86407).

\section{References}

1- Assadi SN, Esmaily H, Mostaan L. Comparison of sensory-neural hearing between firefighters and office workers. Int J Prev Med2013; 4(1): 115-9.

2- Assadi SN. Cardiovascular Disorders Risk Factors in different Industries of Iran. Int J Prev Med2013; 4(6):
728-33.

3- Edward JP. Occupational stress, In: Ladou J, ed. Occupational and environmental Medicine. 4th ed. New York: McGraw-Hill; 2007. pp: 603-18.

4- Rosch JW, Sauter SL. Psychologic stressors and work. In: Rosenstock L, ed. Textbook of clinical occupational and environmental medicine. 2 nd ed. St. Louis, Mo: Elsevier Saunders; 2005. pp: 931-42.

5- Elo AL, Assessment of mental stress factors at work. In: Zenz C, Dickerson OB, Hovath JR EP, eds. Occupational medicine. 3th ed. Chicago: Mosby; 1994. pp: 945-59.

6- Centers for Disease Control and Prevention. Stress at work, 2009; [1 screen]. Available at URL: https:/www. cdc.gov/niosh/docs/99-101. Accessed Sep12, 2010.

7- Mets JT, LaDou J. Diagnosis of absenteeism. In: Zenz C, Dickerson OB, Hovath JR EP, eds. Occupational medicine. 3th ed. Chicago: Mosby; 1994. pp: 987-98.

8- Assadi SN, Behdani F, Seyyed Nouzadi M, Farhadi M. Effect of work place parameters on mental health of physicians and nurses of emergency and non-emergency wards. Journal of Fundament Mental Health2010; 12(3): 612-9.

9- Kerr R, McHugh M, McCrory M. HSE management standards and stress related work outcomes. Occup Med2009; 59: 574-79.

10- Assadi SN. Risk of early menopausal symptoms in clinical workers. Iran J Nurs Midwifery Res2014; 19(6): 569-73.

11- Assadi SN. Occupational medicine. 1st ed. Iran (Mashhad): Mashhad University of Medical Sciences; 2011. pp: 11-2.

12- Dunn DE, Rabinowitz PM. Noise. In: Rosenstock L(Ed), Textbook of Clinical Occupational and Environmental Medicine, 2nd ed. Ed by Elsevier Saunders, Philadelphia, USA, 2005, p. 902

13- Schindler DN, Jackler RK, Robinson ST. Hearing loss. In: Ladou J, ed. Occupational and environmental medicine. 4th ed. New York: McGraw-Hill; 2007. pp: 104-20.

14- Lewis R, Metals. In: Ladou J, ed. Occupational and environmental medicine. 4th ed. New York: McGrawHill; 2007. pp: 429-59.

15- Moline JM, Landrigan PJ. Lead. In: Rosenstock L, Cullen MR, Brodkin CA, Redlich CA, eds.Textbook of clinical occupational and environmental medicine. 2nd ed. Philadelphia: Elsevier Saunders; 2005. pp: 969-70.

16- Franzblau A, Carol Fromes M. Lead. In: Rosenstock L, Cullen M, Andrew Brodkin C, Redlich C, eds. Textbook of clinical occupational and environmental medicine, 2nd ed. Amsterdam: Elsevier publication; 2005; 979-82.

17- Rosengerg J, Cone JE, Katz EA. Solvents. In: Ladou $\mathrm{J}$, ed. Occupational and environmental medicine. 4th ed. 
New York: McGraw-Hill; 2007. pp: 503-36

18-Kuschner WG, Blanc PD. Gases and other inhalants. In: Ladou J, ed. Occupational and Environmental Medicine. 4th ed. New York: McGraw-Hill; 2007. pp:572-83.

19- Rempel DM, Janowitz IL. Ergonomics and the prevention of occupational injuries. In: Ladou J, ed. Occupational and Environmental Medicine. 4th ed. New York: McGraw-Hill; 2007. pp: 153-78

20- Halpern M. Ergonomics and occupational biomechanics. In: Rom WN, ed. Environmental and occupational Medicine. 4th ed. Philadelphia: Williams and Wilkins; 2007.pp: 905-23

21- Fischman ML. Building-Associated Illness. In: Ladou J, ed. Occupational and Environmental Medicine. 4th ed. New York: McGraw-Hill; 2007. pp: 744-56

22- Hodgson MJ, Adorisio MR. Exposures in indoor environments. In: Rosenstock L, ed. Textbook of clinical occupational and environmental medicine. 2nd ed. St. Louis, Mo: Elsevier Saunders; 2005. pp: 1133-42.

23- Holma B. Indoor air pollution. In: zenz C, Dickerson OB, Hovath JR EP, eds. Occupational medicine. 3th ed. Chicago: Mosby; 1994. pp: 1067-78

24- Thurston GD, Wallace LA. Air pollution: outdoor and indoor sources. In: Rom WN, ed. Environmental and occupational Medicine. 4th ed. Philadelphia: Williams and Wilkins; 2007. pp:1381-99

25- Assadi SN. Sick building syndrome and building related illness.1st ed. Iran (Mashhad): Mashhad University of Medical Sciences; 2012. pp: 21-32.

26- Research and evaluation; indoor air pollution, World Health Organization,2011; [1 screens]. Available at URL: http:// www.euro.who.int/data/assets/pdf file/0009/128169/ e94535. pdf Accessed Sep11, 2012.

27- Markowitz SB. The role of surveillance in occupational health. In: Rom WN, ed. Environmental and occupational Medicine. 4th ed. Philadelphia: Williams and Wilkins; 2007. pp: 9-21.

28- Cohen BS. Industrial hygiene measurement and control. In: Rom WN, ed. Environmental and occupational Medicine. 4th ed. Philadelphia: Williams and Wilkins; 2007. pp:1764-78.

29- LaDou J. Health. In: Rom WN, ed. Environmental and occupational Medicine. 4th ed. Philadelphia: Williams and Wilkins; 2007. pp:1720-35.

30- Harber P. Impairment and disability. In: Rosenstock L, ed. Textbook of clinical occupational and environmental medicine. 2 nd ed. St. Louis, Mo: Elsevier Saunders; 2005. pp: 147-60.

31- Bennett P, Williams Y, Page N, Hood K, Woollard M. levels of mental health problems among UK emergency ambulance workers. Emerg med J2004; 21(2): 235-36. 32- Chan AO, Huak CY. Influence of work environment on emotional health in a health care setting. Occup Med2004; 54(3): 207- 12.

\footnotetext{
Copyright(C) 2016 ASP Ins. This open-access article is published under the terms of the Creative Commons Attribution-NonCommercial 4.0 International License which permits Share (copy and redistribute the material in any medium or format) and Adapt (remix, transform, and build upon the material) under the Attribution-NonCommercial terms.
} 